\title{
Magnetic nanoparticles as targeted delivery systems in oncology
}

\author{
Sara Prijic ${ }^{1}$ and Gregor Sersa ${ }^{2}$ \\ ${ }^{1}$ Nanotesla Institute, Ljubljana, Slovenia \\ ${ }^{2}$ Institute of Oncology Ljubljana, Department of Experimental Oncology, Ljubljana, Slovenia \\ Received 10 November 2010 \\ Accepted 5 January 2011 \\ Correspondence to: Prof. Gregor Serša, Institute of Oncology Ljubljana, Zaloška 2, SI-1000 Ljubljana, Slovenia. E-mail: gsersa@onko-i.si \\ Disclosure: No potential conflicts of interest were disclosed.
}

Background. Many different types of nanoparticles, magnetic nanoparticles being just a category among them, offer exciting opportunities for technologies at the interfaces between chemistry, physics and biology. Some magnetic nanoparticles have already been utilized in clinical practice as contrast enhancing agents for magnetic resonance imaging (MRI). However, their physicochemical properties are constantly being improved upon also for other biological applications, such as magnetically-guided delivery systems for different therapeutics. By exposure of magnetic nanoparticles with attached therapeutics to an external magnetic field with appropriate characteristics, they are concentrated and retained at the preferred site which enables the targeted delivery of therapeutics to the desired spot. Conclusions. The idea of binding chemotherapeutics to magnetic nanoparticles has been around for 30 years, however, no magnetic nanoparticles as delivery systems have yet been approved for clinical practice. Recently, binding of nucleic acids to magnetic nanoparticles has been demonstrated as a successful non-viral transfection method of different cell lines in vitro. With the optimization of this method called magnetofection, it will hopefully become another form of gene delivery for the treatment of cancer.

Key words: magnetic nanoparticles; nanotechnology; delivery systems; oncology; magnetofection; cancer therapy; magnetic targeting

\section{Introduction}

Nanotechnology is an interdisciplinary field of technological developments on the nanometer scale offering comprehensive applications also to biomedicine. Engineering particles a several tens of nanometers in diameter has opened new possibilities for targeting cells within an organism either for diagnostic or therapeutic purposes.

Magnetically-guided drug or gene targeting using magnetic nanoparticles is a promising approach for cancer chemotherapy and cancer gene therapy. The rationale behind these two treatment modalities is based on binding either chemotherapeutics or nucleic acids onto the surface of magnetic nanoparticles which are directed to and/ or retained at the tumor by means of an external magnetic field. Researchers have been studying magnetically-guided drug targeting since the late 1970 's ${ }^{1}$, however, magnetically-guided gene targeting has emerged as rapid and efficient approach in the beginning of the new millennium. ${ }^{2}$ Magnetic nanoparticles have been explored predominantly in basic and translational research in the field of oncology although some of them have been already clinically approved as contrast enhancing agents for magnetic resonance imaging (MRI). ${ }^{3}$

\section{Magnetic nanoparticles}

\section{What are nanoparticles?}

To date, there is no uniform definition of a nanoparticle. According to Kreuter, a nanoparticle is a solid colloidal particle ranging in size from 1 to $1000 \mathrm{~nm} .{ }^{4}$ In nanomedicine, »nano « can be applied to materials or surfaces that are intentionally altered and manipulated at nanometer scale result- 

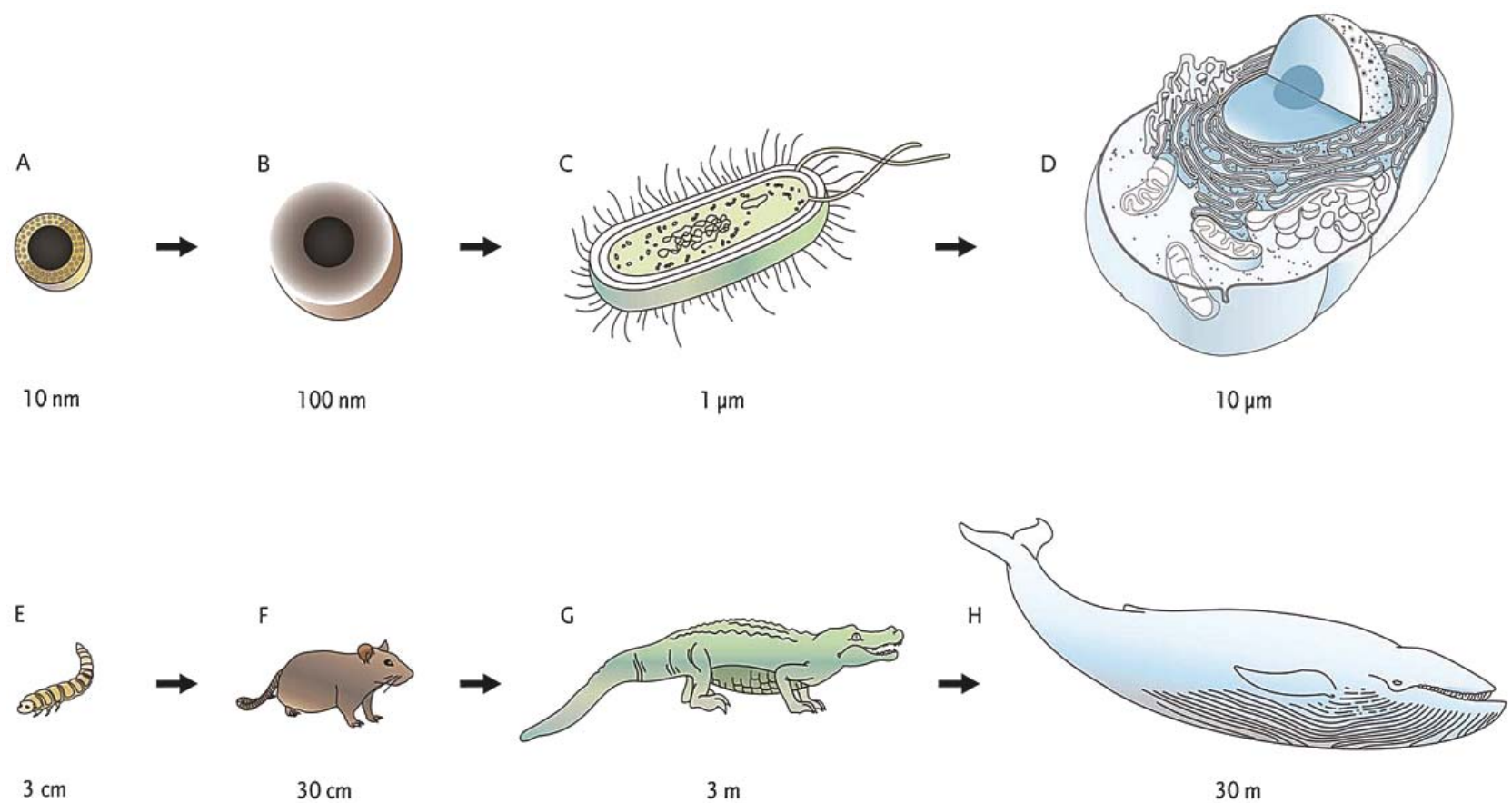

FIGURE 1. Illustrative demonstration of size comparison of a nanoparticle at the microscopic level with corresponding relations on the macroscopic level. Sizes at the microscopic level (A-D) are equivalent to the ones at the macroscopic level (E-H). Magnetic nanoparticle coated with a thin inorganic layer (A), magnetic nanoparticle coated with an organic polymer (B), prokaryotic cell (C) and eukaryotic cell (D) are in the same size relation as a mealworm $(E)$, a rat $(F)$, an alligator $(G)$ and a blue whale $(H)$, respectively.

ing in new properties. ${ }^{5}$ Besides the differences in size, nanoparticles are also distinguished based on their shape and chemical composition (Table 1).

Despite the fact that many nanoparticles measure more than $100 \mathrm{~nm}$ in one dimension, a novel explanation of a nanoparticle based on the following foundations has emerged. First, the majority of nanoparticles for biomedical applications are prepared as colloidal dispersions, i.e. homogenous chemical mixtures of two separated phases. The homogeneity of dispersed-phase particles into a continuous-phase aqueous medium is only possible if dispersed-phase particles have a diameter between 5 and $200 \mathrm{~nm} .{ }^{6}$ Second, unique differences of physical properties that distinguish nanoparticles from atoms as well as from the bulk material are the most prominent below $100 \mathrm{~nm}$. Hence, a nanoparticle is defined as a particle of any kind of material which has one or more dimensions equal to or smaller than $100 \mathrm{~nm}$ (Figure 1). ${ }^{7}$

\section{What are magnetic nanoparticles?}

Nanoparticles consisting of iron, nickel and/or cobalt which exhibit magnetic properties are called magnetic nanoparticles. ${ }^{8}$ Elemental manganese which has a complex crystal structure and unusual magnetic properties can also display magnetic behavior after special physicochemical treatment. ${ }^{9}$

Briefly, the magnetic properties of a material are the reflection of magnetization which arises from magnetic moments of unpaired electrons due to their orbital motion around the nucleus of an atom and intrinsic spinning around their axes. Due to the thermal fluctuations of magnetic moments that reverse direction, some magnetic nanoparticles exhibit superparamagnetic properties which are defined as the nonappearance of magnetic behavior when the magnetic field is not present. ${ }^{10}$ Superparamagnetic properties are observed at sizes smaller than $15 \mathrm{~nm}$ for iron oxide maghemite $\left(\gamma-\mathrm{Fe}_{2} \mathrm{O}_{3}\right) .{ }^{11}$ Hence, magnetic nanoparticles which are small enough, composed of iron oxide and display magnetic behavior only in the presence of a magnetic field are called superparamagnetic iron oxide nanoparticles (SPIONs). It is essential to use SPIONs in biomedical applications since the permanent magnetic behavior of magnetic particles within an organism would be redundant or even destructive when the magnetic field is removed. For example, magnetically induced deformation of endosomes containing paramagnetic nanoparticles 
TABLE 1. Classification of nano-sized delivery systems by chemical compounds and shape. Magnetic nanoparticles which are most often used in biomedical applications are shadowed

\begin{tabular}{|c|c|c|c|c|}
\hline \multicolumn{4}{|c|}{ CHEMICAL COMPOUNDS } & \multirow{2}{*}{$\begin{array}{l}\text { SHAPE } \\
\text { Liposomes }\end{array}$} \\
\hline \multirow{7}{*}{ ORGANIC } & \multirow{3}{*}{ NATURAL } & LIPIDS & Egg phosphatidylcholine (EPC), egg phosphatidyl glycerol (EPG) & \\
\hline & & PROTEINS & Human serum albumin (HSA), gelatin & Nanoparticles* \\
\hline & & CARBON HYDRATES & Chitosan, alginate & Nanoparticles* \\
\hline & \multirow{5}{*}{ SYNTHETIC } & \multirow[t]{2}{*}{ LIPIDS } & $\begin{array}{l}\text { Dipalmitoyl phosphatidylcholine (DPPC), dimyristoyl } \\
\text { phosphatidylcholine (DMPC), dimyristoyl phosphatidylglycerol } \\
\text { (DMPG), dipalmitoyl phosphatidic acid (DPPA), distearoyl } \\
\text { phosphatidylcholine, cholesterol (Ch) }\end{array}$ & Liposomes \\
\hline & & & $\begin{array}{l}\text { Tricaprin, trilaurin, trimylistin, tripalmitin with gliceryl } \\
\text { monostearate, cetyl palmitate, stearic acid }\end{array}$ & $\begin{array}{l}\text { Solid lipid } \\
\text { nanoparticles }\end{array}$ \\
\hline & & POLYMERS & $\begin{array}{l}\text { Homopolymers: } \\
\text { Poly(alkylcyanoacrylate) (PACA), poly(2-hydroxyethyl } \\
\text { methacrylate) (pHEMA), } \\
\text { poly(N-(2-hydroxypropyl)methacrylamide (pHPMA), } \\
\text { polyvinylpyrrolidone (PVP), poly(methyl methacrylate) (PMMA), } \\
\text { polyorthoesters, polycaprolactone (PCL), } \\
\text { poly(vinyl alcohol) (PVA), } \\
\text { poly(acrylic acid) (PAA), } \\
\text { polylactides (PLA) } \\
\text { Copolymers: } \\
\text { Poly(alkylcyanoacrylate)-co-poly(ethylene glycol), poly(lactid } \\
\text { acid)-co-poly(glycolic acid) (PLGA), poly(L,L-lactide-co-L- } \\
\text { aspartic acid), poly(ethylene-co-vinyl acetate) (PEVA) }\end{array}$ & $\begin{array}{l}\text { Dendrimers } \\
\text { Nanoparicles* } \\
\text { Nanocomposites } \\
\text { Nanobrushes } \\
\text { Nanotubes } \\
\text { Micelles } \\
\text { Nanogels }\end{array}$ \\
\hline & & SURFACTANTS & $\begin{array}{l}\text { Cationic: } \\
\text { Sodium dodecyl sulfate (SDS) } \\
\text { Anionic: } \\
\text { Cetyl trimethylammonium bromide (CTAB) } \\
\text { Non-ionic: } \\
\text { Copolymers of poly(ethylene oxide) and poly(propylene oxide) }\end{array}$ & Micelles \\
\hline \multirow{2}{*}{$\begin{array}{l}\text { ORGANIC \& } \\
\text { INORGANIC }\end{array}$} & & LIPIDS & $\mathrm{DPPC} / \mathrm{Ch} / \mathrm{Y}-\mathrm{Fe}_{2} \mathrm{O}_{3}, \mathrm{Fe}_{3} \mathrm{O}_{4}$ & Magnetic liposomes \\
\hline & \multirow{7}{*}{ MAGNETIC } & POLYMERS & $\mathrm{Ni}$-Zn-ferrite/ $\mathrm{SiO}_{2}$, $\mathrm{Fe}-\mathrm{Ni} /$ polymer, Co/polymer, $\mathrm{PMMA} / \mathrm{a}-\mathrm{Fe}_{2} \mathrm{O}_{3}$ & Nanocomposites \\
\hline \multirow{10}{*}{ INORGANIC } & & COMPOUNDS & $\mathrm{Ni}-\mathrm{Fe} / \mathrm{SiO}_{2}, \mathrm{Co} / \mathrm{SiO}_{2}, \mathrm{Fe}-\mathrm{Co} / \mathrm{SiO}_{2}, \mathrm{Fe} / \mathrm{Ni}$-ferrite, Ni-Zn-ferrite $/ \mathrm{SiO}_{2}$ & Nanocomposites \\
\hline & & \multirow{8}{*}{ COMPOUNDS } & $\begin{array}{l}\text { Iron: } \\
\mathrm{Y}-\mathrm{Fe}_{2} \mathrm{O}_{3}, \mathrm{Fe}_{3} \mathrm{O}_{4}\end{array}$ & Nanoparticles* \\
\hline & & & $\mathrm{MgFe}_{2} \mathrm{O}_{4^{\prime}} \mathrm{MnFe}_{2} \mathrm{O}_{4^{\prime}}, \mathrm{FePt}, \mathrm{NiFe}_{2} \mathrm{O}_{4}$ & \\
\hline & & & $\begin{array}{l}\text { Nickel: } \\
\mathrm{NiO}, \mathrm{NiFe}_{2} \mathrm{O}_{4}\end{array}$ & Nanoparticles* \\
\hline & & & $\begin{array}{l}\text { Cobalt: } \\
\mathrm{CO}_{3} \mathrm{O}_{4}, \mathrm{CoFe}_{2} \mathrm{O}_{4}\end{array}$ & Nanorods \\
\hline & & & $\begin{array}{l}\text { Manganese: } \\
\mathrm{Mn}_{3} \mathrm{O}_{4}, \mathrm{MnO}_{2}\end{array}$ & \\
\hline & \multirow{4}{*}{$\begin{array}{l}\text { NON- } \\
\text { MAGNETIC }\end{array}$} & & CdSe/ZnS & Nanocrystals \\
\hline & & & $\begin{array}{l}\mathrm{ZnO}, \mathrm{Au}, \mathrm{Ag}, \mathrm{Cu}, \mathrm{CdSe} / \mathrm{ZnS}, \mathrm{GaN}, \mathrm{TiO}_{2}, \mathrm{C}, \mathrm{TiC}, \mathrm{VO}_{2}, \mathrm{~V}_{2} \mathrm{O}_{5}, \mathrm{PbS}, \\
\mathrm{CdS}, \mathrm{SiC}, \mathrm{BiPO}_{4}, \mathrm{AOB}\end{array}$ & $\begin{array}{l}\text { Nanorods } \\
\text { Nanoparticles* }\end{array}$ \\
\hline & & & Calcium phosphate & Nanocomposites \\
\hline & & ELEMENTS & C & $\begin{array}{l}\text { Fullerenes } \\
\text { Nanotubes }\end{array}$ \\
\hline
\end{tabular}

* Nanoparticles include nanocapsules and/or nanospheres 
was shown by the transmission electron microscope (TEM). ${ }^{12}$

Most studies discussed in this review refer to SPIONs, however not all of them. Hence, the superior term magnetic nanoparticles will be used also for SPIONs in order to make the manuscript more lucid and organized whereas the term SPIONs will be used only when emphasizing the importance of superparamagnetic behavior of the nanoparticles. The majority of magnetic nanoparticles as targeted delivery systems are chemically iron oxides (Table 1). Iron is essential to nearly all known organisms and even endogenic iron oxide nanoparticles were detected in the human hippocampus. ${ }^{13,14}$ However, at the cellular basis, iron oxide causes direct cytotoxicity due to the generation of oxygen and nitrogen-based atoms with an unpaired electron, i.e. reactive oxygen and nitrogen species (ROS and RNS)..$^{15}$ Therefore, magnetic nanoparticles are predominantly prepared through the use of core-shell methodology. As reviewed by Gupta and Gupta, the magnetic core of iron oxide nanoparticles is composed of magnetite $\left(\mathrm{Fe}_{3} \mathrm{O}_{4}\right)$ and/or maghemite $\left(\gamma-\mathrm{Fe}_{2} \mathrm{O}_{3}\right)$ whereas their shell surface coating can be of organic compounds, including surfactants and synthetic or natural polymers, or inorganic material, such as silica, carbon, precious metals or oxides. ${ }^{16}$ Synthesis of core-shell type magnetic nanoparticles is important due to the several reasons: (i) protection of the magnetic core from oxidation, (ii) protection of the surface from chemical reactions, (iii) avoidance of aggregates and agglomerates formation due to Van der Waals forces, hydrophobic effects and magnetic attractions, (iv) facility of the various therapeutics attachment and (v) amplification of the cellular uptake rate. ${ }^{17}$

Biocompatibility of magnetic nanoparticles depends on the type of their surface coating which can be biodegradable (e.g. certain polymers) or non-biodegradable (e.g. silica) as well as on their size. The thickness of the coating determines the total size of magnetic nanoparticles, i.e. coating with an inorganic material in general results in smaller particles below $100 \mathrm{~nm}$ whereas a polymer coating is predominantly reflected in larger particles above $100 \mathrm{~nm} .18,19$ The type of the coating determines characteristics of the particle surface, such as hydrophilicity and surface charge.

For biomedical applications magnetic nanoparticles are predominantly prepared as ferrofluids, i.e. magnetic liquids, thus their surface charge is established by ionization of surface groups or by adsorption of charged species of a surrounding liquid medium onto the particle surface which re- sults in a layer around the particle. The potential difference between the surrounding liquid medium and the layer around the particle is called the zeta potential. Particles with a zeta potential higher than $30 \mathrm{mV}$, either positive or negative, will repel each other, stay asunder and result in a stable ferrofluid. ${ }^{6}$

\section{Why use magnetic nanoparticles?}

The use of magnetic nanoparticles as drug or gene delivery systems can contribute to the effectiveness of cancer therapy in many ways. First, an advantage of using magnetic nanoparticles over non-magnetic ones is that magnetic behavior allows monitoring and quantitative determination of their biodistribution by MRI, which facilitates optimal dosing in cancer therapy. Second, targeting of tumors by magnetic nanoparticles can overcome some supplementary hindrances in more efficient treatment of cancer, such as insufficient penetration of certain therapeutics from the bloodstream into the tumor. Third, targeting of tumors with magnetically-guided nanoparticles provides site specificity and thus selectivity of the therapy, which results in reduced side effects and lower cost of the therapy. And last, exploiting the magnetic field as the driving force represents a noninvasive therapeutic approach. ${ }^{10}$

\section{How to exploit magnetic nanoparticles?}

The basic principle of using magnetic nanoparticles for targeting in oncology is to increase antitumor efficacy while at the same time reduce undesired systemic side effects towards normal tissues by (i) passive targeting, (ii) active targeting and/or (iii) targeting with an external magnetic field. Passive and active targeting can be achieved irrespective of nanoparticles possessing magnetic behavior. Passive targeting is referred to the extravasation of nanoparticles from the blood-stream into the tumor due to disorganized and leaky tumor vasculature..$^{20}$ Active targeting is related to appropriate ligands, predominantly monoclonal antibodies, their fragments, inhibitors of tyrosine kinase domains and most recently aptamers, which actively target tumor markers and are attached to nanoparticles. ${ }^{21}$ Ligands can target extracellular matrix, surface receptors on endothelial cells of tumor vessels or pericytes and tumor cell surface receptors. ${ }^{22}$ On the other hand, targeting by means of an external magnetic field can only be possible in the case of magnetic nanoparticles. Combining active target- 
ing and targeting with a magnetic field provides double-targeting where the magnetic field represents an initial targeting vector that concentrates magnetic nanoparticles in the tumor followed by second level active targeting by means of ligands, bound onto the surface of magnetic nanoparticles that are specific for tumor cells.

Magnetic nanoparticles are in most cases manipulated by a magnetic field which is generated by high-field, high-gradient, rare earth magnets, such as neodymium iron boron (Nd-Fe-B) magnets. Nd-Fe-B magnets are the strongest type of permanent magnets which have been commercialized not earlier than $1986 .{ }^{23}$ The basic principle of magnetically-guided targeting is to place a magnet over a targeted site, i.e. a tumor, in order to in situ concentrate and/or retain magnetic nanoparticles.

If targeting with an external magnetic field is in conjunction with bare magnetic nanoparticles with no attached therapeutics, such a kind of cancer therapy relies on intentional obstruction of tumor vessels. Cancer therapy aiming to obstruct tumor vessels with magnetically guided microparticles composed of carbonyl iron was performed in the early 1970s. Unfortunately, the material displayed low in vivo stability as well as a low ability to be guided by the magnetic field. ${ }^{24}$ More than two decades later, magnetic nanoparticles were intravenously administrated to mice prior to applying the magnetic field with a flux density of 200-500 mT for $20 \mathrm{~min}$ above the subcutaneously transplanted colon carcinomas or hypernephromas. This caused complete and permanent tumor remissions due to tumor blood vessels obstruction..$^{25}$ Compared to active targeting with antibody-bound magnetic nanoparticles, targeting with bare magnetic particles by sufficiently long exposure $(6 \mathrm{~h})$ to the magnetic field with a flux density of only $2.5 \mathrm{mT}$ resulted in comparable retention at the targeted site, in this case lungs and heart. ${ }^{26}$

\section{Pathways of magnetic nanoparticles within an organism}

Efficient internalization of magnetic nanoparticles into targeted cells and subsequent therapy outcome are limited by several factors, such as (i) cytotoxicity, (ii) nanoparticle aggregation due to increased surface/volume ratio and (iii) short plasma half-life due to their elimination from the bloodstream by phagocytic cells. In general, biocompatibility of magnetic nanoparticles mainly depends on their physicochemical properties whereas the route of administration and characteristics of an applied magnetic field also affect cellular uptake and biodistribution. ${ }^{27,28}$

\section{Cellular pathways}

It is known that different therapeutics get in contact with cells mainly by Brownian motion during a given incubation time. Hence, the crucial limitation in achieving more efficient delivery of therapeutics to the cells is the lack of contact between the delivery system and cellular surface. The contact between the therapeutics and cellular surface can be increased by exploiting the gravitational force $^{29}$ as well as magnetic force.

\section{Sedimentation}

Manipulating the magnetic force in vitro leads to accelerated sedimentation of magnetic nanoparticles onto the cellular surface and does not directly affect their internalization. ${ }^{30,31}$ Magnetic nanoparticles exposed to Nd-Fe-B magnets with the remanence of approximately $1 \mathrm{~T}$, i.e. the strength of the magnetic field at the core of the magnet, were detected in vitro onto the cellular surface within a few minutes. ${ }^{32}$

\section{Internalization}

Once the magnetic nanoparticles are located onto the cellular surface, fast internalization begins. Results obtained by mechanics modeling demonstrate that particles in the size range of tens to hundreds of nanometers can enter cells even in the absence of clathrin or caveolin-mediated endocytosis. ${ }^{33}$ However, the majority of experimental studies concluded that internalization of magnetic nanoparticles was mediated through endocytosis, beginning with the invagination of the plasma membrane at either clathrin-coated pits or caveolaes. ${ }^{18,31,34-36}$ The extent of involvement of clathrindependent and caveolae-mediated endocytosis seems to be cell dependent. ${ }^{31}$

Irrespective of nanoparticles possessing magnetic behavior, authors of studies have reported about more efficient membrane crossing and cellular uptake of smaller particles in comparison to larger ones, e.g. $10-20 \mathrm{~nm}$ vs. $1000 \mathrm{~nm}$ and $70 \mathrm{~nm}$ vs. $200 \mathrm{~nm}^{37,38}$

Malignant cells are more prone to internalization of magnetic nanoparticles than normal cells (Figure 2). ${ }^{18,35,39,40}$ The reason is that malignant cells 


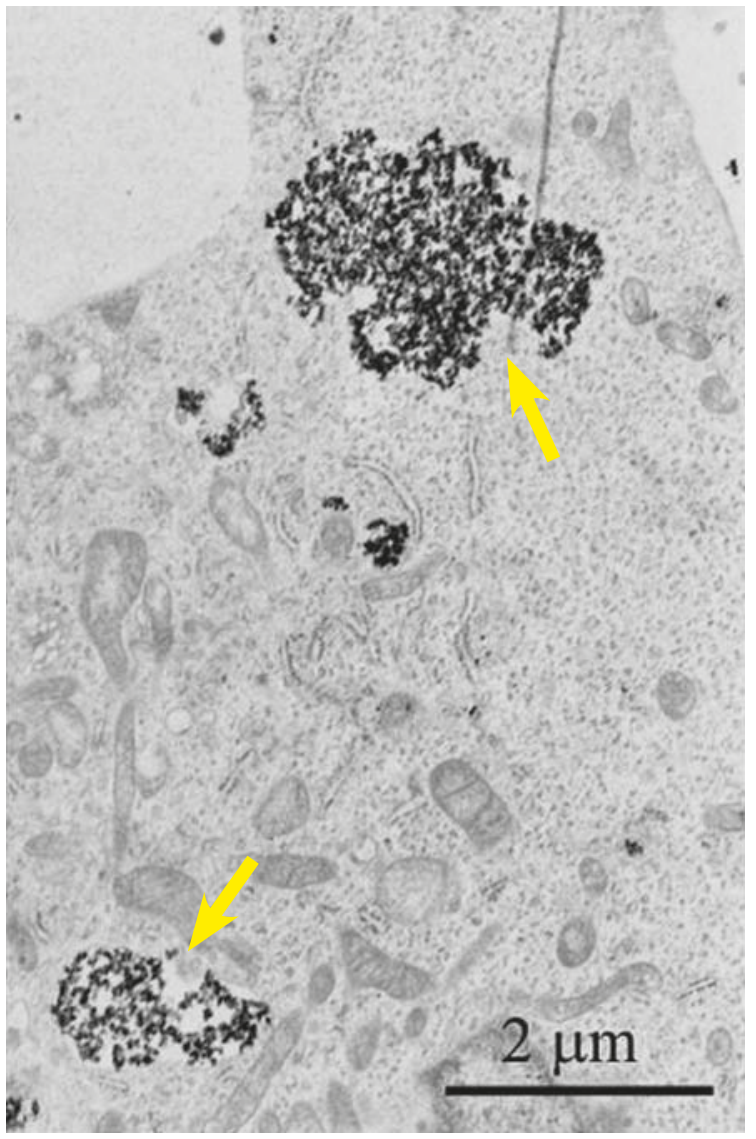

FIGURE 2. Transmission electron micrograph of human melanoma SK-MEL-28 cell, taken $4 \mathrm{~h}$ after the cell has been exposed to $100 \mu \mathrm{g}$ SPIONs/ml. Arrows indicate enlarged endosomes with high accumulation of SPIONs.

possess a higher endocytotic potential than normal cells due to their enhanced requirement for nutrients in virtue of their high metabolic activity and proliferation rate. ${ }^{41}$ This makes magnetic nanoparticles especially suitable for delivery of anticancer therapeutics into tumor cells.

\section{Cellular trafficking}

Once internalized, magnetic nanoparticles with attached therapeutics remain within the maturing endosomes until they fuse with lysosomes where they are exposed to digestive enzymes. Linkage between a magnetic nanoparticle and a therapeutic has to overcome degradation within body fluids but has to achieve fast and simple cleavage once magnetic nanoparticles are internalized into cells. Various molecules can be linked to magnetic nanoparticles in order to release their cargo from the endocytotic-degradative pathway.
In the case of gene delivery, endosomal escape of nucleic acids is in most cases achieved by the proton sponge effect of endosomolytic polymers, such as polyethylenimine (PEI). ${ }^{31,42-44}$ Due to the large number of amino groups PEI possesses a high buffering capacity which in the acidic environment of the endolysosomes induces proton entry and accumulation, followed by passive chloride influx leading to osmotic swelling of the endolysosomes. Endolysosomes burst releasing their content into the cytoplasm. ${ }^{45}$ Irrespective of the applied magnetic field, binding of PEI to the surface of magnetic nanoparticles increased transfection efficiency of anti-GFP siRNA in stably transduced cervical cancer HeLa cells with GFP for $20 \%$ at siRNA concentrations as low as $8 \mathrm{nM} .{ }^{42}$ Moreover, under magnetic field guidance, addition of free PEI to already PEI-modified magnetic nanoparticles resulted in an approximately 8-fold increase in transfection efficiency of the luciferase reporter gene to Swiss albino mouse fibroblasts (NIH 3T3) in comparison to transfection using just PEI-modified magnetic nanoparticles. ${ }^{42}$

However, as PEI is vastly cytotoxic ${ }^{44,46}$, also other molecules are attached to magnetic nanoparticles, such as fusogenic peptides and cell-penetrating peptides (CPPs). ${ }^{28,47,48}$ Fusogenic peptides, e.g. INF7 , are able to form membrane channels in response to low $\mathrm{pH}$ which leads to the disruption of an endosome. ${ }^{49,50}$ CPPs, e.g. Tat peptides, are a family of proteins containing short cationic or amphiphatic polypeptide sequences, termed the protein transduction domain that have the ability to cross cellular membranes while carrying macromolecules. ${ }^{51,52}$

\section{Penetration into the nucleus}

The nuclear membrane allows passive transport of substances below $50 \mathrm{kDa}$ whereas other substances can only enter the nucleus by active transport through nuclear pore complex (NPC). NPC consists of importins, heterodimeric proteins of $\alpha$ and $\beta$ subunits, which bind to a specific recognition sequence called the nuclear localization signals (NLSs) of the importing substance. NLSs consist of arginine and lysine sequences which help in the transportation of the substance from the cytoplasm to the nucleus. ${ }^{53}$ In order to avoid the use of the intrinsic machinery of the viruses to enter the nucleus and to enhance transfection efficacy, synthetic NLSs have been produced and bound to magnetic nanoparticles. For example, magnetic nanoparticles successfully entered the nucleus of HeLa cells only when modified with NLSs peptide. ${ }^{54}$ 


\section{Biodistribution within an organism}

As reviewed by Soenen and Cuyper, biodistribution of magnetic nanoparticles depends on their physicochemical properties, such as size, hydrophilicity and surface charge. ${ }^{15}$ Irrespective of nanoparticles possessing magnetic behavior, with increasing their surface charge and decreasing hydrophilicity, the capacity of plasma protein absorption increases which leads to their recognition by phagocytic cells. ${ }^{55}$ By increasing the size, renal clearance is omitted, however, nanoparticle recognition by phagocytic cells increases which results in their accumulation in the liver, spleen and lymph nodes. ${ }^{56}$

Different in vivo studies in mice and rats showed that magnetic nanoparticles after intravenous administration predominantly accumulated in the liver and spleen: 55\% of the injected iron composing $190 \mathrm{~nm}$ magnetic nanoparticles localized in the liver after $6 \mathrm{~h}$, but was reduced to $20 \%$ after 24 h. ${ }^{57}$ The level of iron in the spleen after 3 weeks corresponded to $25 \%$ of the injected dose. ${ }^{58}$ Significantly increased iron levels were also detected in the heart and brain, however these were notably lower than these in the liver and spleen. ${ }^{57}$ Biodistribution of magnetic nanoparticles in the mice after intraperitoneal route was similar to that of intravenous administration: the highest concentrations of magnetic nanoparticles were observed in liver and spleen. ${ }^{59}$ If magnetic nanoparticles are guided by means of a magnetic field, they concentrate in the area of interest (Figure 3). For example, when $70 \mathrm{~nm}$ magnetic nanoparticles were injected into mice through the tail vein and directed to the heart and kidneys by means of magnetic field with flux density of only $2.5 \mathrm{mT}$ for $6 \mathrm{~h}$, they concentrated in the heart and kidneys as well as in the lungs. ${ }^{26}$ Biodistribution of magnetic nanoparticles after different administration routes is schematically presented in the Figure 3.

\section{Toxicity studies}

\section{Toxicity of magnetic nanoparticles}

Toxicity studies of magnetic nanoparticles are scarce. The first tolerance study with carbohydratecoated magnetic nanoparticles as potential delivery systems was performed in nude mice and showed no median lethal dose $\left(\mathrm{LD}_{50}\right)$, no alterations in the blood haematological and biochemical profiles as well as no organomegalies were observed after injection of magnetic nanoparticles. However, when

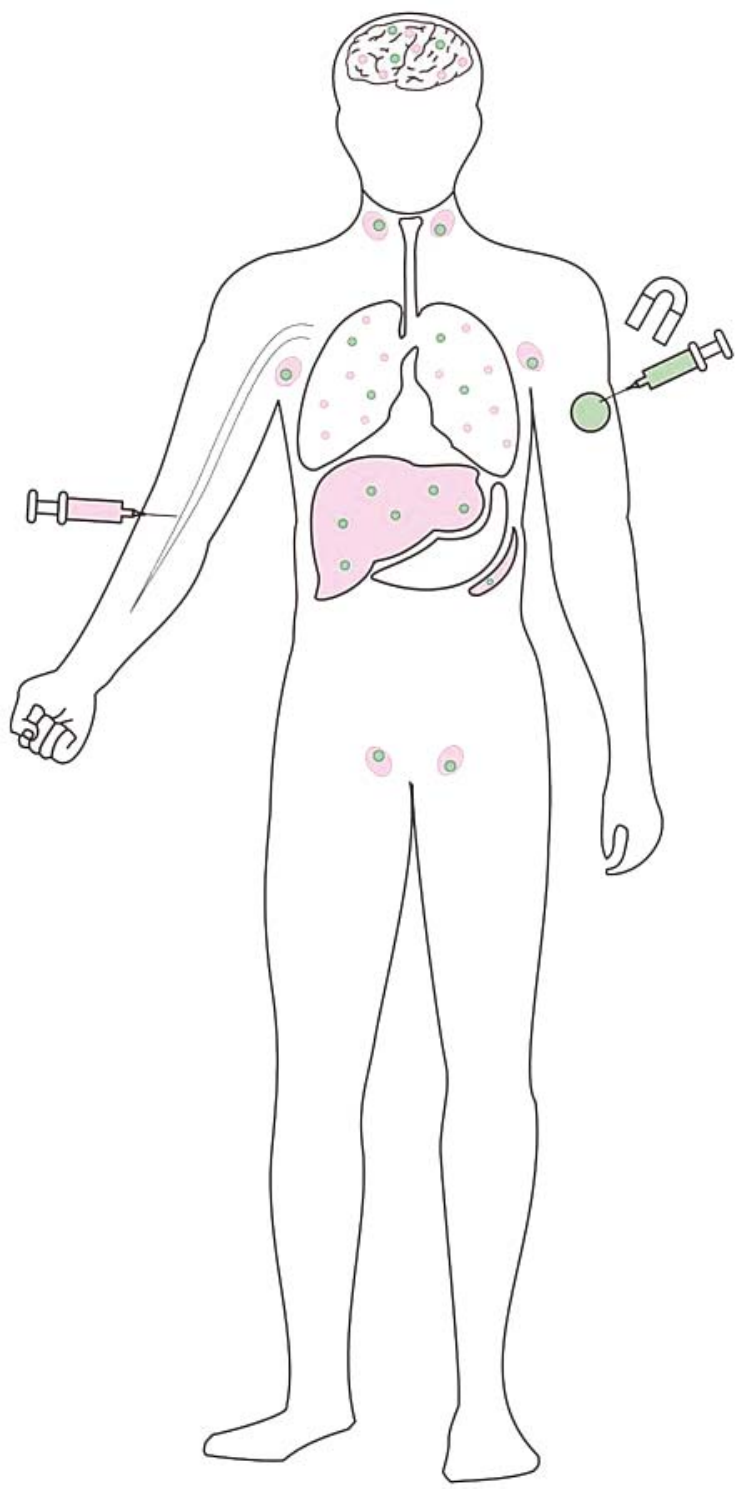

FIGURE 3. Biodistribution of magnetic nanoparticles within the body after different administration routes. After intravenous administration (pink syringe) magnetic nanoparticles predominantly accumulate in the liver, spleen and lymph nodes (pink areas). However, the blood flow also takes them to other organs, e.g. lungs, brain (pink dots). After intra-tumoral administration and exposure to the magnet (green syringe), magnetic nanoparticles concentrate in the fumor (green area). However, a small quantity can also be also found in the organs throughout the body, e.g. liver, lungs, lymph nodes, brain, spleen (green dots), which depends on leakage of the tumoral vasculature.

$10-20 \%$ of the blood volume was infused with the ferrofluid, short episodes of lethargy and resistance of food uptake were detected. ${ }^{25}$ On the other hand tartrate and citrate-coated magnetic nanoparticles, administrated intra-peritoneally in mice, caused severe inflammatory reactions in the peritoneal 
cavity and around the hilum of spleen and kidneys, indicating that adsorption of carboxylic acids at physiological $\mathrm{pH}$ and isotonic conditions did not inevitably result in a biocompatible ferrofluid. ${ }^{60}$ Coating of magnetic nanoparticles with dextran despite of more than 6 months retention in the liver and spleen of mice caused no alterations observable in histology specimens of these organs. ${ }^{61}$ Similarly, histological analysis of liver, spleen and kidney after intravenous administration of oleic acid-coated magnetic nanoparticles did not show any alterations in these organs. However, lipid peroxidation indicating oxidative stress was elevated and returned to a normal value within 3 weeks. ${ }^{57}$

\section{Toxicity of an external magnetic field}

Questions remain about the possibility of adverse side effects related to electromagnetic fields. According to the U.S. National Institute of Environmental Health Sciences (NIEHS), there is a weak association between magnetic field exposure of flux density as small as $0.0003 \mathrm{mT}$ and an increased risk of childhood leukemia. ${ }^{62}$ According to numerous MRI examinations, a static magnetic field of flux densities from 0.5 to $2 \mathrm{~T}$ does not cause any known side effects and therefore the patient compliance is high..$^{63}$ On the other hand, rats developed aversive and avoidance behavior when the field was increased up to ultra-high fields of flux densities of $4 \mathrm{~T}$ and $7 \mathrm{~T}$, respectively. ${ }^{64}$

There are some inconsistent reports about cellular toxicity or adverse side effects caused by magnetic field exposure which might be due to the cell type dependent mechanisms. It seems that cells deriving from mesenchymal descent are more prone to the magnetic field exposure than other normal and malignant cells. ${ }^{47,65-68}$ Evidently, in order to provide assurance that the magnetic field accurately does not cause any side effects there is a vital need to perform additional in vitro as well as in vivo studies.

\section{Applications of magnetic nanoparticles in oncology}

\section{Diagnostic purposes}

For diagnostic purposes magnetic nanoparticles are utilized as contrast enhancing agents for MRI in order to improve spatial resolution and provide earlier lesion detection. ${ }^{69}$ SPIONs are replacing paramagnetic gadolinium-based MRI contrast agents due to their superior in vivo behavior and biocom- patibility with some of them already being FDAapproved. Earliest magnetic nanoparticles for MRI were administered into the bloodstream and within minutes cleared by mononuclear phagocytic cells of the reticuloendothelial system. Their subsequent accumulation into the liver and spleen improved visualization of focal lesions with a few millimeters diameter. ${ }^{70-72}$ In 1996, the first liver-specific MRI contrast agent, Feridex I.V. ${ }^{\circledR}$, came to the market which was soon followed by GastroMARK ${ }^{\circledR}$, a contrast agent for MRI of the gastrointestinal tract. Modification of physicochemical properties of magnetic nanoparticles resulted in their prolonged blood half-life and vascular penetration which enabled visualization of other tissues and organs within the rats. ${ }^{73,74}$ For example, Chertok et al. visualized accumulation of magnetically-guided nanoparticles in experimentally-induced rat gliosarcomas after intravenous administration by MRI. ${ }^{75}$ Currently, magnetic nanoparticles are being investigated for visualization of lymph node metastases which are otherwise undetectable by existent technology equipment. ${ }^{76}$ Moreover, as reviewed by Jain et al., SPIONs with minor macrophage uptake and prolonged blood half-life have found preferential application in sentinel lymph node imaging as contrast enhancing agents for MRI. ${ }^{77}$

Concerning diagnostic, prognostic and even therapeutic implications, magnetic nanoparticles are also used in magnetic-activated cell sorting $\left(\mathrm{MACS}^{\circledR}\right)$ for magnetic separation of different tumor cells and cancer stem cells out of the bloodstream or tissue by the recognition of CD surface antigens. ${ }^{78-81}$ Briefly, magnetic nanoparticles coated with immunospecific agents tag target cells which are then separated from other biological entities by passing through an external magnetic field.

\section{Therapeutic purposes}

For therapeutic purposes no magnetic nanoparticles have yet been approved for clinical use. However, the majority are being investigated as drug or gene delivery systems whereas to a considerably smaller extent they are being explored for the treatment of cancer by magnetic hyperthermia.

\section{Magnetic hyperthermia}

Magnetic hyperthermia is local therapeutic modality for the treatment of cancer which is founded on the fact that magnetic nanoparticles produce heat when exposed to an alternating current (AC) magnetic field. The therapy comprehends administra- 
tion of magnetic nanoparticles into the tumor followed by an AC magnetic field exposure. Cancer cells loaded with magnetic nanoparticles are subjected to irreversible damage of temperatures above $42-43^{\circ} \mathrm{C}$ whereas normal cells withstand temperatures up to $46^{\circ} \mathrm{C} . .^{39}$ Moreover, heat alters some receptor molecules on the surface of cancer cells which enhances their recognition by natural killer cells. ${ }^{82}$ In 2005, the first phase I clinical trial was carried out in a patient with a recurrent prostatic tumor concluding that magnetic hyperthermia is a feasible and well tolerated treatment modality. ${ }^{83}$ Two years later in combination with radiotherapy, magnetic hyperthermia was performed in 14 brain-cancer patients demonstrating that the therapy was well tolerated by all the patients with minimal or no clinical effect. ${ }^{84}$

\section{Drug carriers}

Magnetically-guided drug carriers in the treatment of cancer date back to the late 1970s, however, no such magnetic nanoparticles have yet been clinically approved. Only nanoparticles without magnetic properties, i.e. liposomes encapsulating anthracyclines (daunorubicin and doxorubicin), and nanoparticulate albumin-bound paclitaxel are used for the treatment of different types of solid tumors and metastatic breast cancer, respectively. ${ }^{85}$

The idea of using magnetic microspheres as vehicles for drug delivery in cancer therapy was first introduced by Widder et al. ${ }^{1}$ In 1983 they performed the first preclinical study in rats. Selective targeting with intravenously administrated magnetic albumin microspheres containing low doses of doxorubicin resulted in total remission of $77 \%$ $(17 / 22)$ of tumors after only one regimen of drug therapy. ${ }^{86}$

As late as 1996, the very first preclinical and clinical studies on magnetic nanoparticles for cancer therapy were done. It is essential to mention that the following magnetically-guided drug carriers were barely classified among nanoparticles since they measured $0.5-5.0 \mu \mathrm{m}$. A preclinical study of magnetically-guided nanoparticles as delivery systems in cancer therapy was performed in a xenotransplanted human colon as well as renal cancer tumor-bearing mice. After intravenous injection and magnetic guidance of epidoxorubicin attached to magnetic nanoparticles, complete remissions of tumors were observed..$^{25}$ The first clinical phase-I magnetically-guided drugtargeted study was carried out in 14 patients with advanced unsuccessfully pretreated solid tumors.
Intravenous administration of epidoxorubicin attached to magnetic nanoparticles resulted in transient serum iron elevations in almost all patients after the therapy, which did not cause any clinical symptoms, and in some patients increased ferritin levels in the blood were observed. In 50\% (7/14) of the patients, magnetic nanoparticles were detected within the tumors. However, only a slight reduction of tumor size occurred in merely $14 \%(2 / 14)$ of the patients. ${ }^{87}$

Later, the same research group utilized mitoxantrone attached to magnetic nanoparticles of the ferrofluid (magnetic liquid) (FF-MTX) aiming to compare the antitumor efficacy of FF-MTX given by different administration routes. The treatment was performed in rabbits bearing squamous cell carcinomas (VX-2) which showed complete and permanent remission after intra-arterial administration of FF-MTX. However, intravenous application of FF-MTX did not result in statistically significant tumor remission in comparison to the control group. ${ }^{88}$

The following preclinical and clinical trials of two research groups focused on the delivery of doxorubicin hydrochloride adsorbed to magnetic targeted carriers (MTC-DOX) by selective arterial catheterization of the hepatic artery. ${ }^{89-91} \mathrm{~A}$ preclinical trial was performed in a swine model. By magnetic targeting, extravasation of MTC-DOX through the vascular wall was obtained, leading to their localization and retention in the tissue at the targeted site. The severity of liver necrosis correlated to the severity of embolization following treatment and was observed only in the animals which received the highest dose of MTC-DOX whereas no adverse effects were determined at the MTCDOX low-dose group. ${ }^{89}$ Clinical trials with MTCDOX were carried out in patients with inoperable hepatocellular carcinomas. No clinically significant toxicity was observed. However, all patients experienced abdominal pain during MTC-DOX administration which was intravenously controlled with analgesics. ${ }^{90,91}$ In the first phase I/II study, localization of MTC-DOX in the tumors was achieved in $94 \%(30 / 32)$ of all the patients with one complete and two partial responses. ${ }^{90}$ In the second study MTC-DOX was observed in 100\% (4/4) of the tumors with $64-91 \%$ of the tumor volume loaded with magnetic nanoparticles. However, this resulted in only one partial response. ${ }^{91} \mathrm{~A}$ subsequent phase II/III multinational clinical study with MTCDOX enrolling 240 patients with hepatocellular carcinoma was prematurely stopped as there was no increase in median survival time for MTC-DOX 


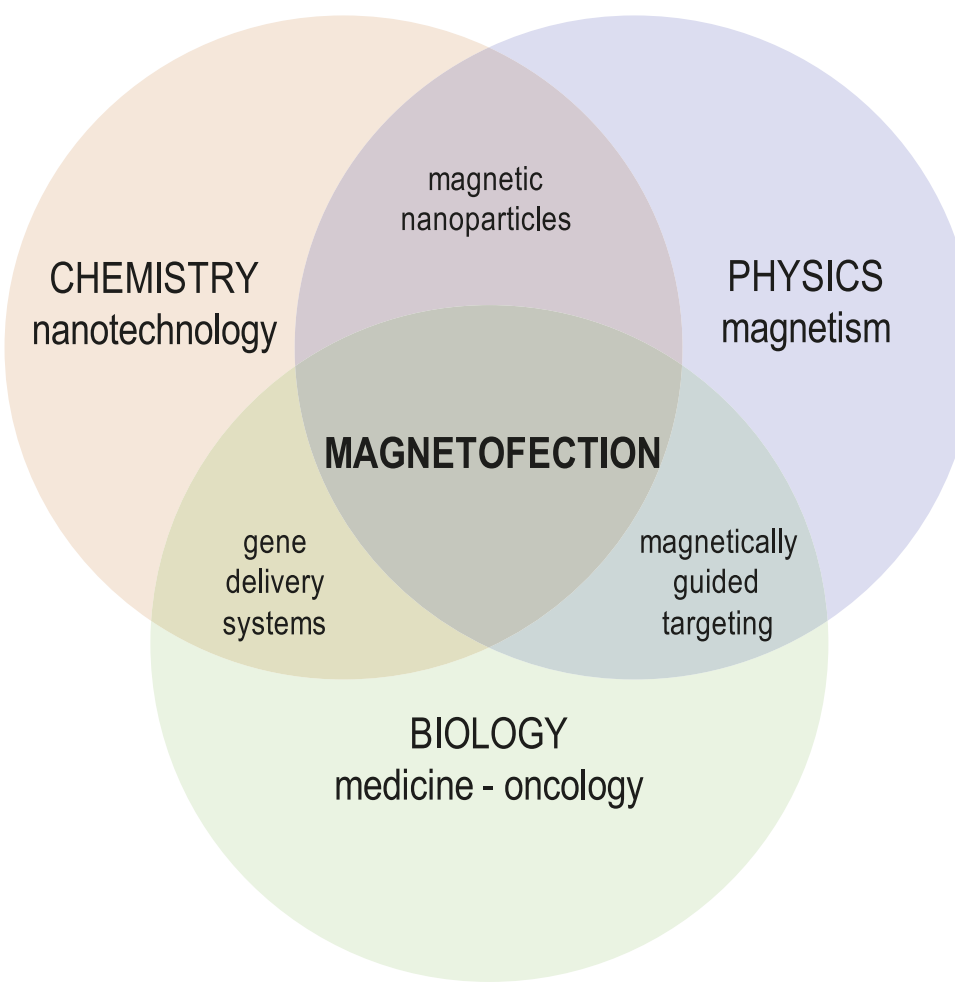

FIGURE 4. Schematic presentation of interdisciplinary approach resulting in magnetofection at the cross-section.

treated patients relative to patients treated with IV doxorubicin..$^{92}$

To sum up, preclinical studies turned out in complete and permanent tumor remission; however, dose escalation clinical trials resulted in no clinically significant toxicities but had a relatively poor tumor response.

\section{Nucleic acid carriers}

In addition to chemotherapy, recent progress in gene therapy has made it a realistic option for the treatment of cancer. ${ }^{93,94}$ The idea of using magnetic nanoparticles as gene delivery systems emerged in the year 2000, combining expertise of chemistry, biology, medicine and physics. This new interdisciplinary approach has already shown some promising results in preclinical studies. ${ }^{95-98}$

Until the new millennium, the majority of studies focusing on gene delivery for therapeutic approaches used viruses as transport vehicles for nucleic acids. In order to avoid the disadvantages of viral based gene delivery, such as receptor dependent host tropism, pre-existing immunity of the host, induced immune response by the virus, potential recombination of viral and host cell ge- netic material and large-scale infrastructure for virion production, new methods have begun developing. ${ }^{99}$

Non-viral methods of gene transfer can be divided into three major groups: injection of naked plasmid DNA (pDNA), chemical and physical approaches. ${ }^{100}$ In 1990, first in vivo study injecting naked pDNA into mouse muscle was performed. In the injected tissue significant elevations of all three reporter genes encoding chloramphenicol acetyltransferase, luciferase and beta-galactosidase were observed. ${ }^{101}$ Later, injection of naked pDNA was repeated by others, as well as in other organs. ${ }^{102,103}$ In an effort to increase transfection efficiency, development of various physical approaches has begun. The general principle of nucleic acid internalization by physical approaches, which include microinjection, hydrodynamic delivery, biolistics, electroporation, sonoporation and impalefection, is based on disruption of the cell membrane to facilitate nucleic acid uptake. ${ }^{104-109}$ However, nucleic acids still remain exposed to biochemical degradation which reduces transfection efficacy; thus attaching or encapsulating nucleic acids within nanoparticles, which mediate their internalization by membrane fusion and/or endocytosis, results in increased transfection efficiency in vitro in comparison to some physical approaches. ${ }^{110}$

Progress in the field of nanotechnology and new trends in gene biology contributed to the development of a novel method called magnetofection, which unites the advantages of physical and chemical approaches in one system (Figure 4). The method is based on binding the nucleic acids to magnetic nanoparticles that concentrate and transfect cells in the area of interest by means of a magnetic field. ${ }^{2}$ For cancer therapy, a high-field, high-gradient, rare earth permanent magnet, such as Nd-Fe-B magnet, is placed above the solid tumor in order to retain administrated magnetic nanoparticles with bound nucleic acids in situ until they internalize and transfect malignant cells. ${ }^{97,98}$ Although magnetofection is considered a nonviral method of gene transfer, viral vectors can be supplementary attached to magnetic nanoparticles in order to additionally increase transfection efficiency. ${ }^{111}$ In 2000, the use of magnetic microparticles for transfection in vitro was first demonstrated in carcinoma $\mathrm{C} 12 \mathrm{~S}$ cells and in vivo in mice using an adeno-associated virus linked to magnetic microspheres via heparin. The study resulted in enhanced green fluorescent protein (GFP) expression due to the increase in contact between the delivery system and the cell. ${ }^{112}$ In these terms, 
the immunity-based problems arising from the use of viral vectors for gene transfer remain; therefore, studies of virus-associated magnetic nanoparticles will not be discussed in this review.

\section{Magnetofection in vitro and ex vivo}

Currently there are several commercially available magnetic nanoparticles measuring 50 to 200 $\mathrm{nm}$ in diameter, e.g. CombiMAG, PolyMAG and TransMAG ${ }^{\mathrm{PEI}}$, which have been used in many in vitro and some in vivo studies of magnetofection. $2,28,31,42,95-98,113$ It is noteworthy that these vectors represent a hybrid system characterized by the iron oxide inner core and a coat consisting of PEI, which is a well known transfection agent. ${ }^{114}$

All in vitro studies confirmed efficient magnetofection of a variety of cell lines with various nucleic acids, in most cases pDNA followed by small interfering RNA (siRNA), short hairpin RNA (shRNA) and antisense oligonucleotides, associated to magnetic nanoparticles and guided by a magnetic field generated by $\mathrm{Nd}-\mathrm{Fe}-\mathrm{B}$ magnets. 2,28,31,42,95,96 Magnetofection of pDNA encoding GFP on mouse melanoma B16F1 cells is presented in Figure 4. The studies also demonstrated that magnetofection is superior to other standard transfection protocols, mostly lipofection. ${ }^{95,115}$

The first in vitro study demonstrated enhancement in LacZ reporter gene transfection of mouse embryonic fibroblasts NIH3T3 and Chinese hamster ovary (CHO) cells up to several 100-fold compared to transfection in the absence of magnetic field. In addition, a minimal dose of pDNA $(0.1 \mu \mathrm{g})$ was sufficient to achieve high transfection levels. ${ }^{2}$ The highest increase in transfection efficiency of human umbilical vein endothelial cells (HUVEC) with the luciferase reporter gene by magnetofection was about 360 -fold compared to various conventional transfection methods. ${ }^{95}$ However, it is worth to note that magnetic nanoparticles in the latter study were additionally coupled to lipid-based transfection reagents, Effectene ${ }^{\circledR}$ and FuGENE ${ }^{\circledR}$, as well as to a combination of the polymer-lipid transfection enhancer PEI/DOTAP-cholesterol, which greatly contributed to the increase in transfection efficiency. Other in vitro and ex vivo magnetofection-based studies also showed enhanced transfection efficacy of luciferase, enhanced GFP (EGFP) and Discosoma sp. red fluorescent protein (DsRed) reporter genes to various cell lines, however, to a lesser extent, i.e. from 3-fold to 36-fold. ${ }^{116-119}$

Refinements of the technique resulted in significantly reduced time needed for the transfec-

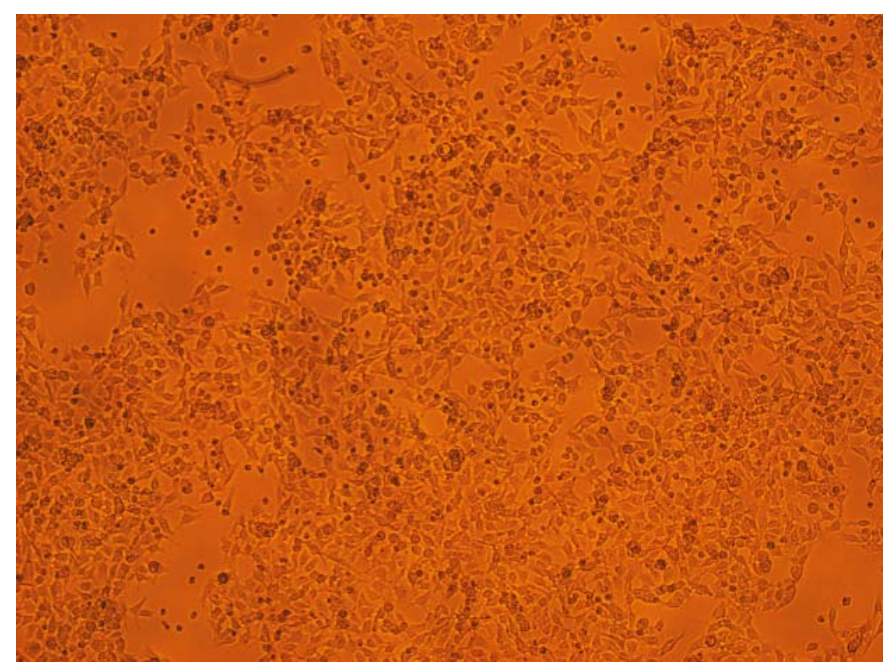

(A)

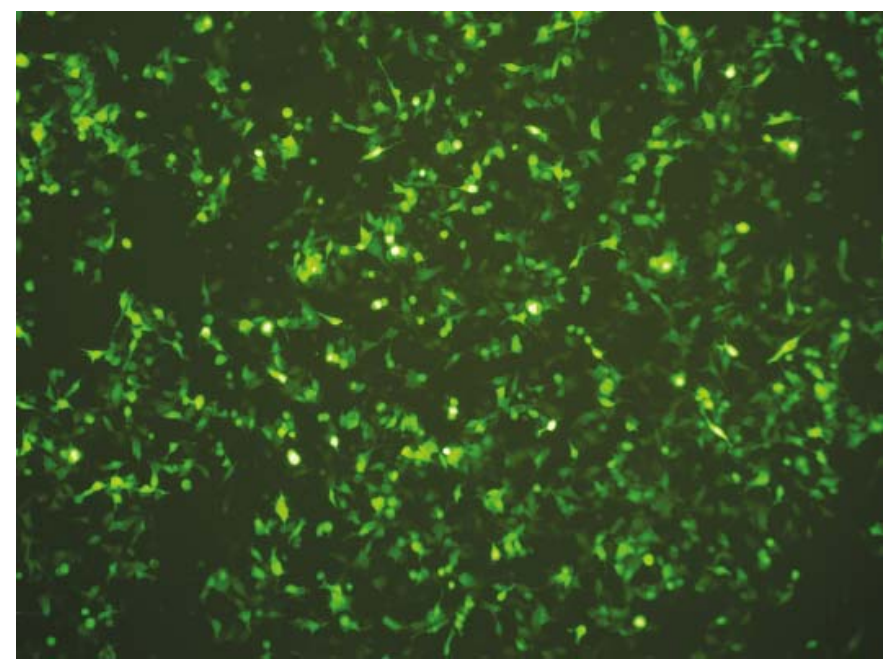

(B)

FIGURE 5. Photomicrograph of mouse melanoma B16Fl cells, taken $24 \mathrm{~h}$ after magnetofection of pDNA encoding GFP was performed, demonstrating high transfection efficiency. Image taken under visible light condition (A) and image taken under fluorescence epi-illumination (B) (x 60 magnification).

tion process to be completed (transfection time) in comparison to other non-viral gene delivery approaches. Under magnetic field guidance, the transfection time of HUVEC with oligodesoxynucleotides (ODN) against the p22 phox subunit of endothelial $\mathrm{NAD}(\mathrm{P}) \mathrm{H}$-oxidase bound to magnetic nanoparticles was decreased to a few minutes whereas it required $24 \mathrm{~h}$ when ODN were coupled only to Effectene ${ }^{\circledR} .{ }^{96}$ Cationic lipid-coated magnetic nanoparticles associated with transferrin demonstrated a 300-fold increase in transfection efficiency of the luciferase reporter gene in comparison to well established and efficient PEI polyplexes and Lipofectin ${ }^{\mathrm{TM}}$ after 15 min incubation. ${ }^{115}$ Similarly, Chorny et al. managed to efficiently transfect aortic smooth muscle cells A10 and bovine aortic 
endothelial cells (BAEC) with the use of polymercoated magnetic nanoparticles attached to pDNA encoding EGFP just after $15 \mathrm{~min}$ of exposure to the magnetic field. The negligible transfection was observed in the absence of the magnetic field. ${ }^{120}$

Therefore, magnetofection is defined as enhanced delivery of nucleic acids associated with magnetic nanoparticles to the cells under the influence of a magnetic field. ${ }^{2}$

The majority of magnetofection studies utilized a static magnetic field, however, two research groups have also focused on the application of a pulsed magnetic field. The Swiss group utilized electromagnets and reported that transfection efficiency of reporter genes was the highest when magnetic nanoparticles were first sedimented by exposure to the permanent magnet before application of the pulsating magnetic field. ${ }^{121}$ The mechanism behind this observation could be an alteration in the permeability of cell membranes by pulsed magnetic field after the increased sedimentation by a static magnetic field enhanced the contact between the cells and magnetic nanoparticles. In another study of the same group, at least a 6-fold increase in transfection efficiency of the EGFP reporter gene to various primary cell lines was shown when a combination of static and pulsating magnetic field was used compared to the presence of static magnetic field alone. The transfection was the lowest when the cells were exposed only to the pulsed magnetic field. ${ }^{119}$ On the other hand, the American group utilized a computer-controlled stepper motor-driven horizontally oscillating magnet array system which produced increased magnetic field strength and a gradient with no heating in comparison to electromagnets used by the Swiss group. The lateral motion of the horizontally oscillating magnet array system at an amplitude $200 \mu \mathrm{m}$ and frequency 2 $\mathrm{Hz}$ promoted extra energy and mechanical stimulation which increased particles sedimentation onto the cellular surface. The result was a 4 -fold greater transfection of the luciferase reporter gene to human lung epithelial NCI-H292 cells than that of Lipofectamine ${ }^{\mathrm{TM}} 2000$ and more than a 2-fold greater than transfection performed under a static magnetic field. The oscillating array system also had little or no effect on cell viability. ${ }^{122}$

\section{Magnetofection in vivo}

Although authors of several studies have reported about the suitability of magnetofection of reporter genes in vitro, some improvements are still re- quired to make the method efficient enough to be widely used for in vivo applications.

To demonstrate that magnetofection of reporter genes in vivo is feasible, two studies using pDNA encoding beta-galactosidase and luciferase were performed in rats, mice and pigs.,113 In addition, a magnetofection study using Cy3-fluorescencelabeled antisense ODN was carried out in mice by the same extended research group. ${ }^{96}$ Initial preclinical in vivo trial of $L a c Z$ reporter gene delivery was performed in ilea lumens of rats using viral vector-free magnetic nanoparticles and in stomach lumens of mice using adenovirus-associated magnetic nanoparticles. Efficient transfection was observed in lamina propria of ileum as well as in crypts of fundic glands after $20 \mathrm{~min}$ of exposure to the magnetic field. For additional proof-of-principle, magnetofection of the luciferase reporter gene was done in the ear veins of pigs. Luciferase expression was observed in all vein samples under the influence of magnetic field whereas no transfection was found distally from the magnet position and in other organs. ${ }^{2}$ In another study, the same magnetic nanoparticles were coupled to lipid 67 (GL67) and pDNA encoding luciferase, thus forming ternary complexes. GL67 is a cationic lipid considered as the gold standard for in vivo airway gene transfer. The authors aimed to compare magnetofection efficacy of ternary complexes to transfection efficacy of plane GL67/pDNA. Surprisingly, in vivo transfection of the murine nasal epithelium with plane GL67/pDNA resulted in an approximately 90-fold higher luciferase expression than that observed by magnetofection. The authors referred the poor outcome of magnetofection to the size of magnetic nanoparticles $(200 \mathrm{~nm})$, their coating and characteristics of the magnetic field applied, suggesting that smaller particles with a modified surface coating could have been more efficient in crossing extracellular barriers as well as intracellular membranes in the airway epithelium. ${ }^{113}$ The third in vivo study was performed in mice in order to investigate whether magnetofection is feasible strategy for directing antisense ODN, complexed to magnetic nanoparticles, to a targeted site via arterial catheterization. Nd-Fe-B magnet was held above the right testis throughout the infusion of Cy3-labeled antisense ODN, coupled to magnetic nanoparticles, via femoral catheter and for another additional $4 \mathrm{~min}$. The study demonstrated site-specific magnetofection of the ipsilateral arterioles of the cremaster muscle whereas contralateral vessels of the same muscle, which were not exposed to an external magnetic field, were not transfected. ${ }^{96}$ 
Magnetofection of therapeutic genes in vivo was published in two papers, both dealing with veterinary clinical trial consisting of dose-escalation neoadjuvant gene therapy to surgery. ${ }^{97,98}$ The aim of neoadjuvant immunostimulatory gene therapy in the treatment of cancer is to induce local production of cytokines which triggers systemic antitumor immunity. ${ }^{123}$ Both studies were carried out in feline fibrosarcomas by the same research group in which immunostimulatory therapeutic genes were applied by magnetofection. In the study of Jahnke et al., dose-escalation study was performed with a combination of pDNA encoding three different cytokines: feline interleukin-2 (feIL-2), feline interferon-gamma (feIFN- $\gamma$ ) and feline granulocyte-macrophage colony-stimulating factor (feGMCSF). Altogether six cats developed local recurrences during 1-year observation period, four of them received the highest dose of the total amount of pDNA (1350 $\mu \mathrm{g}$ pDNA; $450 \mu \mathrm{g}$ per plasmid) ${ }^{97}$ That was clarified by bell-shaped dose dependence of IL-2. ${ }^{124,125}$ Moreover, one cat in this group (12.5\%) showed adverse events. However, the study concluded that the highest dose was well tolerated as the only adverse events occurred once and were self-limiting. Due to the early recurrences the authors suggested to include in a subsequent phase-II study also the second highest dose of pDNA (450 $\mu \mathrm{g}$ pDNA; $150 \mu \mathrm{g}$ per plasmid). ${ }^{97}$ In the study of Hüttinger et al., magnetofection of pDNA encoding feGM-CSF was performed 14 days prior to surgery. Results of the study demonstrated that ten of the treated animals (50\%) were recurrence-free after 360 days of observation. Moreover, the highest dose $(1250 \mu \mathrm{g})$ of pDNA applied was shown to be safe for phase-II testing. ${ }^{98}$

\section{Future directions}

New technologies have enabled synthesis of biocompatible magnetic nanoparticles that can be functionalized with therapeutic molecules. The transfection method using magnetic nanoparticles, which are manipulated by an external magnetic field, is called magnetofection. It is a promising strategy that can lead to targeted delivery of pDNA carrying therapeutic genes, siRNA or other gene therapy approaches. Due to its physical properties of delivery, the approach is feasible on different tissues; foreseen can be tumors, muscle, skin and others. In this field of research very little was done. When the protocols for synthesis of magnetic nanoparticles and their functionalization with nu- cleic acids are standardized along with contemporary optimization of magnetic field parameters, the field will open for broader and in depth investigations, that may in near future also bring magnetofection into the clinical trials.

\section{Acknowledgement}

The authors thank Andrej Žnidaršič, $\mathrm{PhD}$, and Vladimir B. Bregar, PhD, from Nanotesla Institute for introducing us to the "nano world«. Useful comments and criticism of the manuscript by Maja Čemažar, $\mathrm{PhD}$, are considerably recognized. We thank Mireille Treeby, $\mathrm{PhD}$, for proof-reading of the manuscript. The authors acknowledge the financial support of the Slovenian Research Agency (program P3-0003, project J3-2069).

\section{References}

1. Widder KJ, Senyei AE, Ranney DF. Magnetically responsive microspheres and other carriers for the biophysical targeting of antitumor agents. Adv Pharmacol Chemother 1979; 16: 213-71.

2. Scherer $F$, Anton $M$, Schillinger $U$, Henke J, Bergemann $C$, Krüger $A$, et al. Magnetofection: enhancing and targeting gene delivery by magnetic force in vitro and in vivo. Gene Ther 2002; 9: 102-9.

3. Morana G, Salviato E, Guarise A. Contrast agents for hepatic MRI. Cancer Imaging 2007; 7 Spec No A: S24-7.

4. Kreuter J. Drug targeting with nanoparticles. Eur J Drug Metab Pharmacokinet 1994; 19: 253-6.

5. Filipponi L, Sutherland D, editors. Nanotechnology: a brief introduction [Internet]. Aarhus: University of Aarhus; 2007 [cited 2010 March 11]. Available from: http://www.nanocap.eu.

6. Hunter R. Electrokinetics and the zeta potential. In: Hunter R, editor. Foundations of colloid science. New York: Oxford University Press; 2001. p. 373-434.

7. Auffan M, Rose J, Bottero JY, Lowry GV, Jolivet JP, Wiesner MR. Towards a definition of inorganic nanoparticles from an environmental, health and safety perspective. Nat Nanotechnol 2009; 4: 634-41.

8. Gubin S. Introduction. In: Gubin S, editor. Magnetic nanoparticles. Weinheim: Wiley-VCH; 2009. p. 1-24.

9. Bondi JF, Oyler KD, Ke X, Schiffer P, Schaak RE. Chemical synthesis of airstable manganese nanoparticles. J Am Chem Soc 2009; 131: 9144-5.

10. Alexiou C, Jurgons R. Magnetic drug targeting. In: Andrä W, Nowak H, editors. Magnetism in medicine: a handbook. Berlin: Wiley-VCH; 2007. p. 596-605.

11. Lowery T. Nanomaterials-based magnetic sensors switch biosensors. In Kumar C, editor. Nanomaterials for the life sciences. Weinheim: Wiley-VCH; 2009. p. 3-54.

12. Wilhelm C, Cebers A, Bacri JC, Gazeau F. Deformation of intracellular endosomes under a magnetic field. Eur Biophys J 2003; 32: 655-60.

13. Kirschvink JL, Kobayashi-Kirschvink A, Woodford BJ. Magnetite biomineralization in the human brain. Proc Natl Acad Sci U S A 1992; 89: 7683-7.

14. Schultheiss-Grassi PP, Wessiken R, Dobson J. TEM investigations of biogenic magnetite extracted from the human hippocampus. Biochim Biophys Acta 1999; 1426: 212-6. 
15. Soenen SJ, De Cuyper M. Assessing cytotoxicity of (iron oxide-based) nanoparticles: an overview of different methods exemplified with cationic magnetoliposomes. Contrast Media Mol Imaging 2009; 4: 207-19.

16. Gupta AK, Gupta M. Synthesis and surface engineering of iron oxide nanoparticles for biomedical applications. Biomaterials 2005; 26: 3995-4021.

17. Phenrat T, Saleh N, Sirk K, Tilton RD, Lowry GV. Aggregation and sedimentation of aqueous nanoscale zerovalent iron dispersions. Environ Sci Technol 2007; 41: 284-90.

18. Prijic S, Scancar J, Romih R, Cemazar M, Bregar VB, Znidarsic A, et al. Increased cellular uptake of biocompatible superparamagnetic iron oxide nanoparticles into malignant cells by an external magnetic field. J Membr Biol 2010; 236: 167-79.

19. Chertok B, David AE, Yang VC. Polyethyleneimine-modified iron oxide nanoparticles for brain tumor drug delivery using magnetic targeting and intra-carotid administration. Biomaterials 2010; 31: 6317-24

20. Matsumura $\mathrm{Y}, \mathrm{Maeda} \mathrm{H}$. A new concept for macromolecular therapeutics in cancer chemotherapy: mechanism of tumoritropic accumulation of proteins and the antitumor agent smancs. Cancer Res 1986; 46: 6387-92.

21. Byrne JD, Betancourt T, Brannon-Peppas L. Active targeting schemes for nanoparticle systems in cancer therapeutics. Adv Drug Deliv Rev 2008; 60 1615-26.

22. Leuschner C, Kumar CS, Hansel W, Soboyejo W, Zhou J, Hormes J. LHRHconjugated magnetic iron oxide nanoparticles for detection of breast cancer metastases. Breast Cancer Res Treat 2006; 99: 163-76.

23. Babincova $\mathrm{M}$, Babinec $\mathrm{P}$. Magnetic drug delivery and targeting: principles and applications. Biomed Pap Med Fac Univ Palacky Olomouc Czech Repub 2009; 153: 243-50.

24. Mosso JA, Rand RW. Ferromagnetic silicone vascular occlusion: a technic for selective infarction of tumors and organs. Ann Surg 1973; 178: 663-8.

25. Lübbe AS, Bergemann C, Huhnt W, Fricke T, Riess $H$, Brock JW, et al. Preclinical experiences with magnetic drug targeting: tolerance and efficacy. Cancer Res 1996; 56: 4694-701.

26. Kumar A, Jena PK, Behera S, Lockey RF, Mohapatra S. Multifunctional magnetic nanoparticles for targeted delivery. Nanomedicine 2010; 6: 64-9.

27. Chouly C, Pouliquen D, Lucet I, Jeune JJ, Jallet P. Development of superparamagnetic nanoparticles for MRI: effect of particle size, charge and surface nature on biodistribution. J Microencapsul 1996; 13: 245-55.

28. Mykhaylyk O, Zelphati O, Hammerschmid E, Anton M, Rosenecker J, Plank C. Recent advances in magnetofection and its potential to deliver siRNAs in vitro. Methods Mol Biol 2009; 487: 111-46.

29. Luo D, Saltzman WM. Enhancement of transfection by physical concentration of DNA at the cell surface. Nat Biotechnol 2000; 18: 893-5.

30. Plank C, Schillinger U, Scherer F, Bergemann C, Rémy JS, Krötz F, et al. The magnetofection method: using magnetic force to enhance gene delivery. Biol Chem 2003; 384: 737-47.

31. Huth S, Lausier J, Gersting SW, Rudolph C, Plank C, Welsch U, et al. Insights into the mechanism of magnetofection using PEI-based magnetofectins for gene transfer. J Gene Med 2004; 6: 923-36.

32. Plank C, Scherer F, Schillinger U, Bergemann C, Anton M. Magnetofection: enhancing and targeting gene delivery with superparamagnetic nanoparticles and magnetic fields. J Liposome Res 2003; 13: 29-32.

33. Gao H, Shi W, Freund LB. Mechanics of receptor-mediated endocytosis. Proc Natl Acad Sci U S A 2005; 102: 9469-74.

34. Kim JS, Yoon TJ, Yu KN, Noh MS, Woo M, Kim BG, et al. Cellular uptake of magnetic nanoparticle is mediated through energy-dependent endocytosis in A549 cells. J Vet Sci 2006; 7: 321-6.

35. Ma YJ, Gu HC. Study on the endocytosis and the internalization mechanism of aminosilane-coated Fe3O4 nanoparticles in vitro. J Mater Sci Mater Med 2007; 18: 2145-9.

36. Petri-Fink $A$, Chastellain $M$, Juillerat-Jeanneret $L$, Ferrari $A$, Hofmann $H$. Development of functionalized superparamagnetic iron oxide nanoparticles for interaction with human cancer cells. Biomaterials 2005; 26: 2685 94.

37. Prabha S, Zhou WZ, Panyam J, Labhasetwar V. Size-dependency of nanoparticle-mediated gene transfection: studies with fractionated nanoparticles. Int J Pharm 2002; 244: 105-15.
38. Zauner W, Farrow NA, Haines AM. In vitro uptake of polystyrene microspheres: effect of particle size, cell line and cell density. J Control Release 2001; 71: 39-51.

39. Jordan A, Scholz R, Wust P, Schirra K, Schiestel T, Schmidt H, et al. Endocytosis of dextran and silan-coated magnetite nanoparticles and the effect of intracellular hyperthermia on human mammary carcinoma cells in vitro. J Magn Magn Mater 1999; 194: 185-96.

40. Wilhelm C, Billotey C, Roger J, Pons JN, Bacri JC, Gazeau F. Intracellular uptake of anionic superparamagnetic nanoparticles as a function of their surface coating. Biomaterials 2003; 24: 1001-11.

41. Sincai M, Ganga D, Ganga M, Argherie D, Bica D. Antitumor effect of magnetite nanoparticles in cat mammary adenocarcinoma. J Magn Magn Mater 2005; 293: 438-41.

42. Mykhaylyk O, Antequera YS, Vlaskou D, Plank C. Generation of magnetic nonviral gene transfer agents and magnetofection in vitro. Nat Protoc 2007; 2: 2391-411.

43. Wei $\mathrm{W}, \mathrm{Xu} \mathrm{C}, \mathrm{Wu} \mathrm{H}$. Use of PEl-coated magnetic iron oxide nanoparticles as gene vectors. J Huazhong Univ Sci Technolog Med Sci 2004; 24: 618-20.

44. Chen CB, Chen JY, Lee WC. Fast transfection of mammalian cells using superparamagnetic nanoparticles under strong magnetic field. J Nanosci Nanotechnol 2009; 9: 2651-9.

45. Godbey WT, Wu KK, Mikos AG. Tracking the intracellular path of poly(ethylenimine)/DNA complexes for gene delivery. Proc Natl Acad Sci U S A 1999; 96: 5177-81.

46. Florea BI, Meaney C, Junginger HE, Borchard G. Transfection efficiency and toxicity of polyethylenimine in differentiated Calu-3 and nondifferentiated COS-1 cell cultures. AAPS PharmSci 2002; 4: E12.

47. Smith CA, de la Fuente J, Pelaz B, Furlani EP, Mullin M, Berry CC. The effect of static magnetic fields and tat peptides on cellular and nuclear uptake of magnetic nanoparticles. Biomaterials 2010; 31: 4392-400.

48. Song HP, Yang JY, Lo SL, Wang Y, Fan WM, Tang XS, et al. Gene transfer using self-assembled ternary complexes of cationic magnetic nanoparticles, plasmid DNA and cell-penetrating Tat peptide. Biomaterials 2010; 31: 769-78.

49. Murata M, Takahashi S, Kagiwada S, Suzuki A, Ohnishi S. pH-dependent membrane fusion and vesiculation of phospholipid large unilamellar vesicles induced by amphiphilic anionic and cationic peptides. Biochemistry 1992; 31: 1986-92.

50. Plank C, Zatloukal K, Cotten M, Mechtler K, Wagner E. Gene transfer into hepatocytes using asialoglycoprotein receptor mediated endocytosis of DNA complexed with an artificial tetra-antennary galactose ligand. Bioconjug Chem 1992; 3: 533-9.

51. Green M, Loewenstein PM. Autonomous functional domains of chemically synthesized human immunodeficiency virus tat trans-activator protein. Cell 1988; 55: 1179-88.

52. Frankel $A D$, Bredt $D S$, Pabo CO. Tat protein from human immunodeficiency virus forms a metal-linked dimer. Science 1988; 240: 70-3.

53. Xylourgidis $\mathrm{N}$, Fornerod $\mathrm{M}$. Acting out of character: regulatory roles of nuclear pore complex proteins. Dev Cell 2009; 17: 617-25.

54. Xu C, Xie J, Kohler N, Walsh EG, Chin YE, Sun S. Monodisperse magnetite nanoparticles coupled with nuclear localization signal peptide for cell-nucleus targeting. Chem Asian J 2008; 3: 548-52.

55. Müller RH, Maassen S, Weyhers H, Mehnert W. Phagocytic uptake and cytotoxicity of solid lipid nanoparticles (SLN) sterically stabilized with poloxamine 908 and poloxamer 407. J Drug Target 1996; 4: 161-70.

56. Storm G, Belliot SO, Daemen T, Lasic DD. Surface modification of nanoparticles to oppose uptake by the mononuclear phagocyte system. Adv Drug Deliv Rev 1995; 17: 31-48

57. Jain TK, Reddy MK, Morales MA, Leslie-Pelecky DL, Labhasetwar V. Biodistribution, clearance, and biocompatibility of iron oxide magnetic nanoparticles in rats. Mol Pharm 2008; 5: 316-27.

58. Mykhaylyk O, Cherchenko A, Ilkin A, Dudchenko N, Ruditsa V, Novoseletz $\mathrm{M}$, et al. Glial brain tumor targeting of magnetite nanoparticles in rats. $J$ Magn Magn Mater 2001; 225: 241-47.

59. Kim JS, Yoon TJ, Yu KN, Kim BG, Park SJ, Kim HW, et al. Toxicity and tissue distribution of magnetic nanoparticles in mice. Toxicol Sci 2006; 89: 338-47. 
60. Lacava ZGM, Azevedo RB, Lacava LM, Martins EV, Garcia VAP, Rébula CA, et al. Toxic effects of ionic magnetic fluids in mice. J Magn Magn Mater 1999; 194: 90-95.

61. Lacava LM, Garcia VAP, Kückelhaus S, Azevedo RB, Sadeghiani N, Buske N, et al. Long-term retention of dextran-coated magnetite nanoparticles in the liver and spleen. J Magn Magn Mater 2004; 272-276: 2434-35.

62. Olden $\mathrm{K}$, editor. Health effects from exposure to power-line frequency electric and magnetic fields [Internet]. Research triangle park (NC): National institute of environmental health sciences (US); 1999 [cited 2010 April 15]. Available from: http://www.niehs.nih.gov/health/docs/niehs-report.pdf.

63. Leszczynski D. Rapporteur report: cellular, animal and epidemiological studies of the effects of static magnetic fields relevant to human health. Prog Biophys Mol Biol 2005; 87: 247-53.

64. Saunders R. Static magnetic fields: animal studies. Prog Biophys Mol Biol 2005; 87: 225-39.

65. Sato K, Yamaguchi H, Miyamoto H, Kinouchi Y. Growth of human cultured cells exposed to a non-homogeneous static magnetic field generated by Sm-Co magnets. Biochim Biophys Acta 1992; 1136: 231-8.

66. Nakahara T, Yaguchi H, Yoshida M, Miyakoshi J. Effects of exposure of CHO-K1 cells to a 10-T static magnetic field. Radiology 2002; 224: 817-22.

67. Coletti D, Teodori L, Albertini MC, Rocchi M, Pristerà A, Fini M, et al. Static magnetic fields enhance skeletal muscle differentiation in vitro by improving myoblast alignment. Citometry PartA 2007; 71A: 846-56.

68. Kotani $H$, Kawaguchi $H$, Shimoaka T, Iwasaka M, Ueno $S$, Ozawa $H$, et al. Strong static magnetic field stimulates bone formation to a definite orientation in vitro and in vivo. J Bone Miner Res 2002; 17: 1814-21.

69. Sun C, Lee JS, Zhang M. Magnetic nanoparticles in MR imaging and drug delivery. Adv Drug Deliv Rev 2008; 60: 1252-65.

70. Saini S, Stark DD, Hahn PF, Wittenberg J, Brady TJ, Ferrucci JT. Ferrite particles: a superparamagnetic MR contrast agent for the reticuloendothelial system. Radiology 1987; 162: 211-6.

71. Saini S, Stark DD, Hahn PF, Bousquet JC, Introcasso J, Wittenberg J, et al. Ferrite particles: a superparamagnetic MR contrast agent for enhanced detection of liver carcinoma. Radiology 1987; 162: 217-22.

72. Weissleder R, Stark DD. Magnetic resonance imaging of liver tumors. Semin Ultrasound CT MR 1989; 10: 63-77.

73. Weissleder R, Elizondo G, Wittenberg J, Rabito CA, Bengele HH, Josephson L. Ultrasmall superparamagnetic iron oxide: characterization of a new class of contrast agents for MR imaging. Radiology 1990; 175: 489-93.

74. Chertok B, David AE, Moffat BA, Yang VC. Substantiating in vivo magnetic brain tumor targeting of cationic iron oxide nanocarriers via adsorptive surface masking. Biomaterials 2009; 30: 6780-7.

75. Chertok B, David AE, Huang Y, Yang VC. Glioma selectivity of magnetically targeted nanoparticles: a role of abnormal tumor hydrodynamics. J Control Release 2007; 122: 315-23.

76. ClinicalTrials.gov [Internet]. Bethesda (MD): National Institutes of Health (US); 1993 - . Pre-operative staging of pancreatic cancer using superparamagnetic iron oxide magnetic resonance imaging (SPIO MRI) [cited 2010 September 12].; [about 3 p.]. Available from: http://clinicaltrials.gov/ct2/ show/NCT00920023 ClinicalTrials.gov Identifier NCT0090023.

77. Jain $R$, Dandekar P, Patravale V. Diagnostic nanocarriers for sentinel lymph node imaging. J Control Release 2009; 138: 90-102.

78. Zhu L, Loo WT, Chow LW. Circulating tumor cells in patients with breast cancer: possible predictor of micro-metastasis in bone marrow but not in sentinel lymph nodes. Biomed Pharmacother 2005; 59: S355-8.

79. Cammareri P, Lombardo Y, Francipane MG, Bonventre S, Todaro M, Stassi G. Isolation and culture of colon cancer stem cells. Methods Cell Biol 2008; 86: 311-24.

80. Joo KM, Nam DH. Prospective identification of cancer stem cells with the surface antigen CD133. Methods Mol Biol 2009; 568: 57-71.

81. Wang GY, Li Y, Yu YM, Yu B, Zhang ZY, Liu Y, et al. Detection of disseminated tumor cells in bone marrow of gastric cancer using magnetic activated cell sorting and fluorescent activated cell sorting. J Gastroenterol Hepatol 2009; 24: 299-306.
82. Multhoff G, Botzler C, Wiesnet M, Müller E, Meier T, Wilmanns W, et al. A stress-inducible 72-kDa heat-shock protein (HSP72) is expressed on the surface of human tumor cells, but not on normal cells. Int I Cancer 1995; 61: 272-9.

83. Johannsen M, Gneveckow U, Eckelt L, Feussner A, Waldöfner N, Scholz R, et al. Clinical hyperthermia of prostate cancer using magnetic nanoparticles: presentation of a new interstitial technique. Int J Hyperthermia 2005; 21: 637-47.

84. Maier-Hauff K, Rothe R, Scholz R, Gneveckow U, Wust P, Thiesen B, et al. Intracranial thermotherapy using magnetic nanoparticles combined with external beam radiotherapy: results of a feasibility study on patients with glioblastoma multiforme. J Neurooncol 2007; 81: 53-60.

85. FDA-Approved Drugs [Internet]. Boston (MA): CenterWatch. 1995 FDA Approved Drugs for Oncology [cited 2010 September 14]; [about 7 p.]. Available from: http://www.centerwatch.com/drug-information/fdaapprovals/drug-areas.aspx?ArealD=12.

86. Widder KJ, Morris RM, Poore GA, Howard DP, Senyei AE. Selective targeting of magnetic albumin microspheres containing low-dose doxorubicin: total remission in Yoshida sarcoma-bearing rats. Eur J Cancer Clin Oncol 1983; 19: 135-9.

87. Lübbe AS, Bergemann C, Riess $H$, Schriever F, Reichardt $P$, Possinger $K$, et al. Clinical experiences with magnetic drug targeting: a phase I study with 4 '-epidoxorubicin in 14 patients with advanced solid tumors. Cancer Res 1996; 56: 4686-93.

88. Alexiou C, Arnold W, Klein RJ, Parak FG, Hulin P, Bergemann C, et al. Locoregional cancer treatment with magnetic drug targeting. Cancer Res 2000; 60: 6641-8.

89. Goodwin SC, Bittner CA, Peterson CL, Wong G. Single-dose toxicity study of hepatic intra-arterial infusion of doxorubicin coupled to a novel magnetically targeted drug carrier. Toxicol Sci 2001; 60: 177-83.

90. Koda J, Venook A, Walser E. A multicenter, phase I/II trial of hepatic intraarterial delivery of doxorubicin hydrochloride adsorbed to magnetic targeted carriers in patients with hepatocellular carcinoma. Eur J Cancer 2002; 38: S18.

91. Wilson MW, Kerlan RK, Fidelman NA, Venook AP, LaBerge JM, Koda J, et al. Hepatocellular carcinoma: regional therapy with a magnetic targeted carrier bound to doxorubicin in a dual MR imaging/ conventional angiography suite--initial experience with four patients. Radiology 2004; 230: 287-93.

92. ClinicalTrials.gov [Internet]. Bethesda (MD): National Institutes of Health (US); 1993 - . Safety and efficacy of doxorubicin adsorbed to magnetic beads Vs. IV doxorubicin in treating liver cancer [cited 2010 May 5]; [about 2 p.]. Available from: http://clinicaltrials.gov/ct/show/NCT00034333 ClinicalTrial.gov Identifier: NCT00034333.

93. Kamensek U, Sersa G. Targeted gene therapy in radiotherapy. Radiol Oncol 2008; 42: 115-35.

94. Cemazar M, Jarm T, Sersa G. Cancer electrogene therapy with interleukin-12. Curr Gene Ther 2010; 10: 300-11.

95. Krötz F, Sohn HY, Gloe T, Plank C, Pohl U. Magnetofection potentiates gene delivery to cultured endothelial cells. J Vasc Res 2003; 40: 425-34.

96. Krötz F, de Wit C, Sohn HY, Zahler S, Gloe T, Pohl U, et al. Magnetofection--a highly efficient tool for antisense oligonucleotide delivery in vitro and in vivo. Mol Ther 2003; 7: 700-10.

97. Jahnke A, Hirschberger J, Fischer C, Brill T, Köstlin R, Plank C, et al. Intratumoral gene delivery of felL-2, felFN-gamma and feGM-CSF using magnetofection as a neoadjuvant treatment option for feline fibrosarcomas: a phase-I study. J Vet Med A 2007; 54: 599-606.

98. Hüttinger C, Hirschberger J, Jahnke A, Köstlin R, Brill T, Plank C, et al. Neoadjuvant gene delivery of feline granulocyte-macrophage colonystimulating factor using magnetofection for the treatment of feline fibrosarcomas: a phase I trial. J Gene Med 2008; 10: 655-67.

99. Lu Y, Madu CO. Viral-based gene delivery and regulated gene expression for targeted cancer therapy. Expert Opin Drug Deliv 2010; 7: 19-35.

100. Russ V, Wagner E. Cell and tissue targeting of nucleic acids for cancer gene therapy. Pharm Res 2007; 24: 1047-57.

101. Wolff JA, Malone RW, Williams P, Chong W, Acsadi G, Jani A, et al. Direct gene transfer into mouse muscle in vivo. Science 1990; 247: 1465-8. 
102. Ardehali A, Fyfe A, Laks H, Drinkwater DC, Qiao JH, Lusis AJ. Direct gene transfer into donor hearts at the time of harvest. J Thorac Cardiovasc Surg 1995; 109: 716-20.

103. Schwarz ER, Speakman MT, Patterson M, Hale SS, Isner JM, Kedes LH, et al. Evaluation of the effects of intramyocardial injection of DNA expressing vascular endothelial growth factor (VEGF) in a myocardial infarction model in the rat--angiogenesis and angioma formation. J Am Coll Cardiol 2000; 35: $1323-30$.

104. Mueller C, Graessmann A, Graessmann M. Mapping of early SV40-specific functions by microinjection of different early viral DNA fragments. Cell 1978; 15: 579-85.

105. Neumann E, Schaefer-Ridder M, Wang Y, Hofschneider PH. Gene transfer into mouse lyoma cells by electroporation in high electric fields. EMBO J 1982; 1: 841-5.

106. Sanford JC, Klein TM, Wolf ED, Allen N. Delivery of substances into cells and tissues using a particle bombardment process. Particul Sci Technol 1987; 5: 27-37.

107. Bao S, Thrall BD, Miller DL. Transfection of a reporter plasmid into cultured cells by sonoporation in vitro. Ultrasound Med Biol 1997; 23: 953-9.

108. Liu F, Song Y, Liu D. Hydrodynamics-based transfection in animals by systemic administration of plasmid DNA. Gene Ther 1999; 6: 1258-66.

109. McKnight T, Melechko A, Griffin G, Guillorn MA, Merkulov VI, Serna F, et al. Intracellular integration of synthetic nanostructures with viable cells for controlled biochemical manipulation. Nanotechnology 2003; 14: 551-6.

110. Ohlfest JR, Freese AB, Largaespada DA. Nonviral vectors for cancer gene therapy: prospects for integrating vectors and combination therapies. Curr Gene Ther 2005; 5: 629-41.

111. Morishita N, Nakagami H, Morishita R, Takeda S, Mishima F, Terazono B, et al. Magnetic nanoparticles with surface modification enhanced gene delivery of HVJ-E vector. Biochem Biophys Res Commun 2005; 334: 1121-6.

112. Mah C, Zolotukhin I, Fraites T, Dobson J, Batich C, Byrne B. Microspheremediated delivery of recombinant AAV vectors in vitro and in vivo. $\mathrm{Mol}$ Ther 2000; 1: 239S.

113. Xenariou S, Griesenbach U, Ferrari S, Dean P, Scheule RK, Cheng SH, et al. Using magnetic forces to enhance non-viral gene transfer to airway epithelium in vivo. Gene Ther 2006; 13: 1545-52.

114. Boussif O, Lezoualc'h F, Zanta MA, Mergny MD, Scherman D, Demeneix $B$, et al. A versatile vector for gene and oligonucleotide transfer into cells in culture and in vivo: polyethylenimine. Proc Natl Acad Sci U S A 1995; 92: 7297-301.

115. Pan X, Guan J, Yoo JW, Epstein AJ, Lee L, Lee RJ. Cationic lipid-coated magnetic nanoparticles associated with transferrin for gene delivery. Int $J$ Pharm 2008; 358: 263-70.

116. Xiang JJ, Nie XM, Tang JQ, Wang YJ, Li Z, Gan K, et al. In vitro gene transfection by magnetic iron oxide nanoparticles and magnetic field increases transfection efficiency. Zhonghua Zhong Liu Za Zhi 2004; 26: 71-4.

117. Yang SY, Sun JS, Liu CH, Tsuang YH, Chen LT, Hong CY, et al. Ex vivo magnetofection with magnetic nanoparticles: a novel platform for nonviral tissue engineering. Artif Organs 2008; 32: 195-204.

118. Ino K, Kawasumi T, Ito A, Honda H. Plasmid DNA transfection using magnetite cationic liposomes for construction of multilayered gene-engineered cell sheet. Biotechnol Bioeng 2008; 100: 168-76.

119. Kamau Chapman SW, Hassa PO, Koch-Schneidemann S, von Rechenberg B, Hofmann-Amtenbrink M, Steitz B, et al. Application of pulsed-magnetic field enhances non-viral gene delivery in primary cells from different origins. J Magn Magn Mater 2008; 320: 1517-27.

120. Chorny M, Polyak B, Alferiev IS, Walsh K, Friedman G, Levy RJ. Magnetically driven plasmid DNA delivery with biodegradable polymeric nanoparticles. FASEB J 2007; 21: 2510-9.

121. Kamau SW, Hassa PO, Steitz B, Petri-Fink A, Hofmann H, HofmannAmtenbrink $M$, et al. Enhancement of the efficiency of non-viral gene delivery by application of pulsed magnetic field. Nucleic Acids Res 2006; 34: e40.

122. McBain $S$, Griesenbach $U$, Xenariou $S$, Keramane A, Batich CD, Alton EWFW, et al. Magnetic nanoparticles as gene delivery agents: enhanced transfection in the presence of oscillating magnet arrays. Nanotechnology 2008; 19: 1-5.
123. Maass G, Schweighoffer T, Berger M, Schmidt W, Herbst E, Zatloukal K, et al. Tumor vaccines: effects and fate of IL-2 transfected murine melanoma cells in vivo. Int J Immunopharmacol 1995; 17: 65-73.

124. Schmidt W, Schweighoffer T, Herbst E, Maass G, Berger M, Schilcher F, et al. Cancer vaccines: the interleukin 2 dosage effect. Proc Natl Acad Sci U S A 1995; 92: 4711-4.

125. Kircheis R, Küpcü Z, Wallner G, Wagner E. Cytokine gene-modified tumor cells for prophylactic and therapeutic vaccination: IL-2, IFN-gamma, or combination IL-2 + IFN-gamma. Cytokines Cell Mol Ther 1998; 4: 95-103. 